\title{
PENGARUH GOOD GOVERNANCE TERHADAP KINERJA KEUANGAN PEMERINTAH DAERAH KABUPATEN PANGKAJENE DAN KEPULAUAN
}

\author{
INDRIANA', MUHAMMAD NASRUN² \\ 1,2Universitas Muhammadiyah Makassar \\ *mnasrun321@unismuh.ac.id
}

\begin{abstract}
This study aims to determine the effect of Good Governance on Local Government Performance Pangkajene and Kepulauan Islands. The type of research used in this study is quantitative by using descriptive statistical analysis method or SPSS 16. The data is processed is the result of questionnaires from the statement of employees of Pangkep District office. Data analysis techniques using simple linear regression formula and descriptive statistical test through SPSS 16 application. Based on the results of data analysis techniques using the formula used to produce the conclusion that the financial performance of local government of Pangkep district is very influential seen from the level of financial performance of local governments Pangkep district.

Keywords: Good Governance, Financial Performance
\end{abstract}

\begin{abstract}
Abstrak
Penelitian ini bertujuan untuk mengetahui pengaruh Good Governance Terhadap Kinerja Pemerintah Daerah Kabupaten Pangkajene dan Kepulauan. Jenis penelitian yang digunakan dalam penelitian ini yaitu kuantitatif dengan menggunakan metode analisis statistik deskriptif atau SPSS 16. Data yang diolah adalah hasil kuesioner dari pernyataan pegawai kantor daerah Kabupaten Pangkep. Teknik analisis data menggunakan rumus regresi linier sederhana dan uji statistik deskriptif melalui aplikasi SPSS 16. Berdasarkan hasil teknik analisis data dengan rumus yang digunakan menghasilkan kesimpulan bahwa kinerja keuangan pemerintah daerah kabupaten pangkep sangat berpengaruh dilihat dari tingkat kinerja keuangan pemerintah daerah kabupaten pangkep.
\end{abstract}

Kata Kunci: Good Governance, Kinerja Keuangan

\section{PENDAHULUAN}

Secara teoritis, tiga pilar masyarakat (community), pasar (market) dan negara (state) adalah bagian yang harus saling mendukung dan mengawasi. Apabila terjadi ketimpangan antara salah satu tiga pilar tersebut, maka demokrasi dan fair corporate governance tidak akan terwujud. Artinya masyarakat memenuhi kewajibannya untuk "taat" kepada negara dengan mematuhi berbagai peraturan dan hukum seperti membayar pajak, retribusi dan lain-lain, demikian halnya negara juga memenuhi kewajibannya dalam melayani masyarakat yang salah satu perwujudannya dilihat bagaimana aparatur pemerintah melayani masyarakat (INCIS:2005).

Pakar study kebijakan, Gilbert, menyatakan bahwa terdapat tiga elemen penting dalam kebijakan, yaitu proses (process), hasil produk (product) dan kinerja (performance). Pada tataran konsepsi secara legal formal, aturan atau perundangan mengenai pelayanan publik non-profit bisa jadi sudah ideal dalam kerangka melayani kepentingan publik.
Namun dalam studi kebijakan dikatakan bahwa product, dalam hal ini pelayanan publik non-profit, bukanlah menjadi parameter utama dalam menentukan performance birokrasi. Disamping process pelibatan stakeholders dalam merumuskan kebijakan, kinerja birokrasi pada tataran implementasi memegang peranan penting untuk melihat seberapa jauh product dipraktikkan dilapangan.

Mahsun (2006) mengatakan bahwa kinerja adalah kemampuan kerja yang ditunjukkan dengan hasil kerja. Berkaitan dengan pelaksanaan kinerja pegawai pemerintah di Indonesia, banyaknya kasus penyimpangan yang ditemukan, menyebabkan kekecewaan dan hilangnya kepercayaan dari masyarakat terhadap pemerintah itu sendiri.

Baik buruknya kinerja para aparatur pemerintahan dapat ditentukan oleh beberapa faktor, namun faktor yang dijadikan pertimbangan ada dua faktor yaitu 2 penerapan prinsip-prinsip good governance dan komitmen organisasi. Dalam sebuah penelitian disebutkan bahwa 
empat faktor good governance yang meliputi akuntabilitas, transparansi, keadilan dan partisipasi berpengaruh terhadap kinerja pegawai (Ningsih dkk, 2011).

Meningkatnya pengetahuan masyarakat dan pengaruh globalisasi menyebabkan banyaknya tuntutan masyarakat terhadap pemerintah mengenai tata kelola pemerintah yang baik, hal ini disebut dengan istilah good governance. Konsep good governance ini memiliki pengaruh dan peranan sangat penting dalam pelaksanaan kinerja pegawai pemerintahan. Oleh karena itu respon terhadap good governance ini sangat tinggi dan pegawai pemerintah pun cukup concern mengenai hal ini. Good governance sering diartikan sebagai kepemerintahan yang baik atau sebagai suatu penyelenggaraan manajemen pembangunan yang solid dan bertanggungjawab yang sejalan dengan prinsip demokrasi dan pasar efisien, penghindaran dari salah alokasi dana investasi dan pencegahan korupsi baik secara politik maupun administrative, menjalankan disiplin anggaran serta penciptaan legal and political framework bagi tumbuhnya aktivitas usaha (Kusmayadi, 2009).

Dari masalah yang terjadi tersebut, penyimpangan - penyimpangan terjadi dalam beberapa perangkat pegawai pemerintah daerah dan dinas Kabupaten Pangkep yang berkaitan dengan pelaksanaan prinsip-prinsip good governance yang belum maksimal dan pemerintah daerah kabupaten Pangkajene dan Kepulauan belum optimal dalam melakukan akuntabilitas kinerjanya terhadap publik, sehingga berpengaruh pula terhadap kualitas kinerja pegawai pemerintah daerah di kabupaten Pangkajene dan Kepulauan yang masih harus diperbaiki.

\section{TINJAUAN PUSTAKA DAN PERUMUSAN HIPOTESIS}

Good Governance diartikan sebagai tata kelola yang baik pada suatu usaha yang dilandasi oleh etika profesional dalam berusaha/berkarya dan wujud dari penerimaan akan pentingnya suatu perangkat peraturan atau tata kelola yang baik untuk mengatur hubungan, fungsi dan kepentingan berbagai pihak dalam urusan bisnis maupun pelayanan publik. Good governance bertujuan untuk menerapkan nilai-nilai manajemen sektor swasta pada manajemen operasional sektor publik agar tujuan dari didirikannya suatu organisasi sektor publik dapat tercapai. Prinsip-prinsip penting good public governance antara lain berupa komitmen yang kuat terhadap integritas, nilai etika dan ketaatan terhadap hukum serta adanya keterbukaan dan ketelitian dalam pelasanaan tugas. Fungsi utama dari penerapan good public governance adalah untuk memastikan bahwa organisasi sektor publik senantiasa bertindak bagi kepentingan masyarakat. Good public governance di Indonesia masalah governance di sektor publik sudah mendapat perhatian yangcukup mendalam sejak pertengahan dekade 2000.

Pengaruh good governance terhadap kualitas pemberian layanan publik menurut Indonesian Governance Index (IGI), governance adalah suatu proses dalam rangka memformulasikan dan mengimplementasikan aturan-aturan, ketentuan- ketentuan dan prioritasprioritas pembangunan melalui interaksi di antara para eksekutif dan para anggota legislatif serta melalui birokrasi dengan partisipasi dari masyarakat sipil maupun masyarakat ekonomi. Penilaian IGI dalam pelaksaaan prinsip good governance meliputi Participation (keikutsertaan), Fairrness (kewajaran), Accountability (kebertanggungjawaban), Transparancy (keterbukaan), Efficiency dan Effectiveness (efektif). Asian Development Bank menegaskan adanya konsensus umum bahwa Good Governance dilandasi oleh 4 (empat) pilar, yaitu : accountability, transparency, participation, effectiveness and efficiency. Munculnya konsep Good 
Governance di Indonesia sebagai reaksi atas perilaku pengelolaan perusahaan yang tidak memperhitungkan stakholder- nya. Hal ini terlihat jelas ketika krisis terjadi di Indonesia sejak tahun 1997. Krisis tersebut memberi pelajaran berharga bahwa pembangunan yang dilaksanakan selama ini ternyata tidak didukung struktur ekonomi yang kokoh. Hampir semua pengusaha besar kita menjalankan roda bisnis dengan manajemen yang tidak baik dan sarat praktek korupsi, kolusi dan nepotisme (Trisnaningsih, 2007). Secara sederhana Governance yang diterjemahkan menjadi tata pemerintahan, adalah penggunaan wewenang ekonomi, politik dan administrasi guna mengelola urusan-urusan negara pada semua tingkat. Tata pemerintahan mencakup seluruh mekanisme, proses dan lembaga-lembaga dimana warga dan kelompok-kelompok masyarakat mengutarakan kepentingan mereka, menggunakan hak hukum, memenuhi kewajiban dan menjembatani perbedaan-perbedaan diantara mereka (Khafid, 2008).

Dalam Peraturan Pemerintah Nomor 101 Tahun 2000 dalam (Siregar, Muhammad Arifin, 2008), tentang Pendidikan dan Pelatihan Jabatan Pegawai Negeri Sipil, dalam penjelasan Pasal 2 (d) mengartikan "Kepemerintahan yang baik sebagai kepemimpinan yang mengembangkan dan menerapkan prinsip-prinsip profesionalisme, akuntabilitas, transparasi, 4 pelayanan prima, demokrasi, efisiensi, efektivitas, supremasi hokum dan dapat diterima oleh seluruh masyarakat".

Secara etimologi, kinerja berasal dari kata prestasi kerja (performance). Menurut Mangkunegara (2005) bahwa istilah kinerja berasal dari kata job performance atau actual performance (prestasi kerja atau prestasi sesungguhnya yang dicapai seseorang) yaitu hasil kerja secara kualitas dan kuantitas yang dicapai oleh seorang pegawai dalam melaksanakan tugasnya sesuai dengan tanggungjawab yang diberikan kepadanya. Kinerja Instansi
Pemerintah Menurut Mahsun (2006) dalam Auditya, Lucy dkk (2013) menyatakan bahwa Kinerja adalah kemampuan kerja yang ditunjukkan dengan hasil kerja. Sedangkang menurut Bastian (2010) dalam Auditya, Lucy dkk (2013), Kinerja adalah gambaran mengenai tingkat pencapaian pelaksanaan suatu kegiatan/program/kebijaksanaan dalam mewujudkan sasaran, tujuan, misi dan visi organisasi yang tertuang dalam perumusan skema strategis (strategic planning) suatu organisasi. Dalam PP No. 58 Tahun 2005

Pasal 1 ayat 35 menyatakan: Kinerja adalah keluaran/hasil dari kegiatan/program yang akan atau telah dicapai sehubungan dengan penggunaan anggaran dengan kuantitas dan kualitas yang terukur. Dalam MenPAN (2007) menyatakan: Kinerja Instansi Pemerintah adalah "gambaran mengenai tingkat pencapaian sasaran ataupun tujuan instansi pemerintah sebagai penjabaran dari visi, misi dan strategi instansi pemerintah yang mengindikasikan tingkat keberhasilan dan kegagalan pelaksanaan kegiatan-kegiatan sesuai dengan program dan kebijakan yang ditetapkan. Menurut Arsyiaty, dkk (2008) dalam Usman dan Lukman (2014), Kinerja instansi merupakan tingkat pencapaian hasil dari suatu kegiatan dalam sebuah instansi pemerintah sehubungan dengan penggunaan dana sesuai dengan kuantitas dan kualitas terukur dengan menggunakan prinsip efisiensi dan efektifitas. Dari beberapa pengertian di atas, kinerja merupakan gambaran tingkat pencapaian dalam pelaksanaan suatu program atau kebijakan yang dilaksanakan sesuai dengan standar tertentu dan bertanggungjawab untuk memberikan laporan kepada pemberikerja. Menurut Mahsun (2006) mengatakan bahwa kinerja adalah kemampuan kerja yang ditunjukkan dengan hasil kerja. Berkaitan dengan pelaksanaan kinerja pegawai pemerintah di Indonesia, banyaknya kasus penyimpangan yang ditemukan, menyebabkan kekecewaan dan hilangnya kepercayaan dari masyarakat 
terhadap pemerintah itu sendiri. Untuk mengembalikan dan bisa memulihkan kepercayaan masyarakat, tentunya diperlukan perubahan di segala bidang, yang tentunya bisa memperbaiki kualitas kinerja pemerintah itu sendiri.

Akuntabilitas kinerja adalah perwujudan kewajiban suatu instansi pemerintah untuk mempertanggung jawabkan

keberhasilan/kegagalan

pelaksanaan

program dan kegiatan yang telah diamanatkan para pemangku kepentingan dalam rangka mencapai misi organisasi secara terukur dengan sasaran/target kineja yang telah ditetapkan melalui laporan kinerja instansi pemerintah yang disusun secara periodik (PerPres Nomor 29 Tahun 2014). Akuntabilitas kinerja diperlukan sebagai pertanggung jawaban terhadap kinerja. Hasil kerja dari pegawai pemerintah dapat diketahui melalui informasi akuntabilitas dari masing-masing instansi pemerintah tersebut. Informasi tentang akuntabilitas diperlukan oleh pemerintah, karena berdasarkan informasi tersebut menjadi bahan pengambilan keputusan pemerintah untuk melakukan perbaikan-perbaikan manajemen dalam penyelenggaraan urusan pemerintah yang lebih baik. Informasi tersebut juga diperlukan sebagai dasar penyusunan laporan pertanggungjawaban kepala pemerintah sebagai penyelenggara pemerintahan kepada masyarakat melalui DPR/D setiap akhir tahun anggaran dan diakhiri jabatan Kepala Pemerintah.

Selanjutnya menurut Mahsun (2006) dalam

Kinkemiza Sektang Paebjikdul mëPedegnksuikan kinerja sebagai gambaran mengenai tingkat pencapaian pelaksanaan suatu kegiatan/program/kebijakan dalam mewujudkan sasaran, tujuan, visi dan misi organisasi yang tertuang dalam strategic planning suatu organisasi.

\section{METODE PENELITIAN}

Penelitian ini menggunakan metode penelitian kuantitatif data didapatkan pada data yang telah diperoleh, disusun, dikelompokkan, dianalisis, kemudian diinterpretasikan sehingga diperoleh gambaran sebenarnya. Dimana penulis mengamati pengaruh Good Governance terhadap kinerja keuangan di instansi pemerintah kabupaten Pangkep. Dalam applied research, dilaksanakan dalam praktek Deskriptif dan Eksplanatori. Penelitian ini dilakukan dilingkungan pemerintah daerah kabupaten Pangkajene dan Kepulauan yang berpusat pada kantor Badan Pengelola Keuangan Daerah (BPKD) dan Dinas Pendapatan Daerah (Dispenda) Pangkajene dan kepulauan di Jalan Sultan Hasanuddin No.1 (Poros Pangkep) dimulai 16 November 2017 sampai dengan 16 Januari 2018. Populasi dalam penelitian ini adalah Satuan Kerja Perangkat Daerah (SKPD) Kabupaten Pangkep. Sampel penelitian terdiri atas 2 yaitu BPKD dan Dispenda terdiri dari 30 responden. Data akan dianalisis dengan uji Statistik Deskriptif menggunakan SPSS dan menggunakan Regresi Linier Sederhana.

\section{HASIL PENELITIAN DAN PEMBAHASAN}

Penelitian ini menghasilkan data melalui penyebaran kuesioner kepada responden yang berjumlah 30 responden dari dua sampel yaitu bagian BPKD dan Dispenda yang disajikan pada Tabel 1

Tabel 1. Statistik Deskriptif Variabel GoodGovernance (X)

Deviation

\begin{tabular}{|c|c|c|c|c|c|}
\hline $\begin{array}{c}\text { Pernyataan } \\
\text { Pernyataan } \\
2\end{array}$ & $\begin{array}{l}30 \\
30\end{array}$ & $\begin{array}{l}4 \\
3\end{array}$ & $\begin{array}{l}5 \\
5\end{array}$ & $\begin{array}{l}4.56 \\
4.11\end{array}$ & $\begin{array}{l}0.52 \\
0.6\end{array}$ \\
\hline $\begin{array}{c}\text { Pernyataan } \\
3\end{array}$ & 30 & 3 & 5 & 4 & 0.277 \\
\hline $\begin{array}{c}\text { Pernyataan } \\
4\end{array}$ & 30 & 3 & 5 & 4.22 & 0.78 \\
\hline $\begin{array}{c}\text { Pernyataan } \\
5\end{array}$ & 30 & 3 & 5 & 3.89 & 0.78 \\
\hline $\begin{array}{c}\text { Pernyataan } \\
6\end{array}$ & 30 & 3 & 5 & 4.22 & 0.67 \\
\hline $\begin{array}{c}\text { Pernyataan } \\
7\end{array}$ & 30 & 3 & 5 & 4.11 & 0.6 \\
\hline
\end{tabular}

Berdasarkan tabel diatas dapat diketahui 
bahwa berkaitan dengan adanya publikasi laporan keuangan tahunan dilakukan secara rutin. Rata-rata jawaban responden adalah 4,56. Ini menyatakan bahwa pejabat pemerintah Kabupaten Pangkajene dan Kepulauan mampu bertanggungjawab dengan mempublikasikan laporan keuangan tahunan secara rutin. Nilai standar deviasi sebesar 0,52 menunjukkan bahwa tidak ada jawaban yang bersifat ekstrim dan tidak outliner. Dikatakan outliner apabila data tersebut lebih besar dari 2,5 standardeviasi. Penelitian ini memiliki batasan masalah pada kinerja keuangan dimana kinerja keuangan dinilai dari aspek non finansial yaitu melalui kinerja manajerial pemerintahan daerah Kabupaten Pangkajene dan Kepulauan. Deskripsi mengenai jawaban responden terhadap kuesioner kinerja keuangan dilaporkan pada Tabel 2.

Tabel 2. Statistik Deskriptif Variabel Kinerja

\begin{tabular}{ccccl}
\multicolumn{5}{c}{ Keuangan $(\mathrm{Y})$} \\
\hline Pernyataan iN & Min & Max & Mean & $\begin{array}{l}\text { Std } \\
\text { Deviation }\end{array}$
\end{tabular}

\begin{tabular}{cccccc}
\cline { 1 - 3 } Pernyataan & 3 & 4 & 5 & 4.33 & 0.5 \\
1 & 0 & & & & \\
Pernyataan & 3 & 3 & 5 & 4.11 & 0.6 \\
2 & 0 & & & & \\
Pernyataan & 3 & 3 & 5 & 4.33 & $0 . \%$ \\
2 & 0 & & & & 0 \\
Pernyataan & 3 & 3 & 5 & 4.22 & 0.6 \\
4 & 0 & & & & 7 \\
Pernyataan & 3 & 3 & 5 & 4.33 & 0.7 \\
5 & 0 & & & & 0 \\
Pernyataan & 3 & 2 & 5 & 4 & 0.9 \\
6 & 0 & & & & 7 \\
Pernyataan & 3 & 4 & 5 & 4.33 & 0.5 \\
7 & 0 & & & & \\
Pernyataan & 3 & 2 & 5 & 4 & 1 \\
8 & 0 & & & & \\
& & & & & \\
\hline
\end{tabular}

Tabel 2 memperlihatkan bahwa rata - rata jawaban responden adalah 4,33 (pernyataan 1,3, 5, 7), pernyataan 2 memiliki nilai 4,11, pernyataan 6 dan 8 memiliki nilai 4 . Nilai ini menunjukkan bahwa responden memiliki kinerja tinggi dalam hal koordinasi. Nilai standar deviasi terkecil yaitu 0,5 dan terbesar adalah 1 , nilai tersebut menunjukkan bahwa tidak ada jawaban yang bersifat ekstrim dan tidak outliner. Dikatakan outliner apabila data tersebut lebih besar dari 2,5 standar deviasi.

Hasil Pengujian Hipotesis

Pengujian hipotesis dilakukan dengan tujuan untuk menguji ada tidaknya pengaruh variabel independen terhadap variabel dependen. Pengujian dengan regresi ditunjukkan dalam tabel-tabel berikut. Metode yang digunakan untuk melakukan analisis regresi adalah metode enter.

Berdasarkan hasil pengolahan data pada tabel 4.5 diperoleh model persamaan regresi sebagai berikut:

$$
\mathrm{Y}=\mathbf{7 . 5 1 5}+\mathbf{8 6 6 \mathrm { X }}+\mathrm{e}
$$

konstanta sebesar 7.515 menyatakan bahwa jika tidak ada good governance, maka kinerja keuangan pemerintah daerah kabupaten pangkajene dan kepulauan akan sebesar 7.515. koefisien $\mathrm{X}=866$, menunjukkan bahwa good governance (X) berpengaruh positif terhadap kinerja keuangan pemerintah daerah kabupaten pangkajene dan kepulauan. Hal ini berarti bahwa jika good governance ditingkatkan,

maka akan meningkatkan kinerja keuangan pemerintah daerah kabupaten pangkajene

aаnкерuіauan.

\section{Hasil Pengukuran Adjusted ${ }^{2}$}

Adjusted $\mathrm{R}^{2}$ pada intinya mengukur seberapa jauh kemampuan model dalam menerangkan variasi variabel, dalam hal ini adjusted digunakan untuk mengetahui seberapa jauh kemampuan good governance (X) dalam kineria keuangan pemerintah uaeran кavupaten pangкалене uan kepulauan (Y). "adjusted dianggap lebih baik dan $\mathrm{R}^{2}$ karena nilai adjusted $\mathrm{R}^{2}$ dapat naik

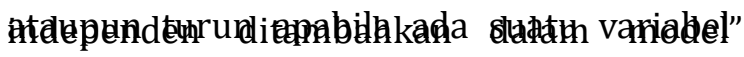
(Ghazali,2005) dalam skripsinya Putri Lubis, 2010. Hasil analisis regresi secara keseluruhan menunjukkan adjusted $\mathrm{R}^{2}$ sebesar 0,450 yang berarti bahwa variabel dependen (kinerja keuangan) dapat dijelaskan oleh variabel independent (good governance) yang dimana apabila nilai adjust $\mathrm{R}^{2}$ dimulai dalam jumlah presentase adalah sebesar $4,50 \%$.

\section{Hasil Uji Signifikan Simultan(Uji-F)}

Uji-F dilakukan untuk mengetahui apakah pemberlakuan good governance

(X) 
berpengaruh simultan terhadap kinerja keuangan ( $\mathrm{Y}$ ) Bila nilai $\mathrm{F}>4$, maka $\mathrm{H}_{0}$ dapat ditolak pada derajat kepercayaan 0,05 (5\%), artinya hipotesis yang diterima adalah bahwa variabel independen dapat berpengaruh terhadap variabel dependen. Dari uji ANNOVA (Analysis of Variance) atau uji-F, maka didapat $\mathrm{F}$ hitung sebesar 24.758 dengan tingkat signifikan 0,000 lebih kecil dibandingkan dengan 0,05. Oleh karena itu, maka model regresi dapat dipakai untuk memprediksi kinerja keuangan pemerintah. Dengan begitu good governance secara simultan berpengaruh terhadap kinerja keuangan pemerintah daerah kabupaten pangkajene dan kepualauan.

\section{Hasil Uji Signifikan Parsial (Uji-T)}

Uji-t dilakukan untuk menguji secara persial berpengaruh terhadap kinerja keuangan pemerintah daerah kabupaten pangkep dan kepulauan (Y). Dari hasil Uji-t dapat diketahui bahwa variabel yang berpengaruh secara persial terhadap kinerja keuangan pemerintah daerah pangkajene dan kepulauan adalah variabel dengan signifikan $<0,05$. Pada tabel 5.8 menunjukkan nilai signifikan masingmasing variabel. Nilai sig good governance $=$ $0,000 \quad(<0,005)$ berarti secara parsial, semakin tinggi good governance maka semakin tinggi pula kinerja keuangan pemerintah daerah kabupaten pangkajene dan kepulauan.

Hasil yang diperoleh secara parsial sejalan dengan penelitian Wala Siti Nurlaela (2015) yang menyatakan bahwa good governance di dinas Pemerintah Daerah Kabupaten Ciamis telah berjalan dengan cukup baik. Hal ini membuktikan bahwa prinsip- prinsip good governance seperti partisipasi, transparansi dan akuntabilitas telah dijalankan dengan cukup baik oleh Pemerintah daerah Kabupaten Ciamis. Hasil penelitian ini secara parsial sejalan dengan penelitian Ira Amelia, Desmiyawat. $\mathrm{Nu}$ Azlina yang menyatakan bahwa good governance berpengaruh signifikan terhadap kinerja pemerintah daerah kabupaten pelalawan.

\section{KESIMPULAN}

Berdasarkan data-data yang ada, penelitian ini bertujuan untuk menguji apakah good governance berpengaruh terhadap kinerja keuangan pemerintah daerah kabupaten Pangkajene dan Kepulauan. Pengujian hipotesis dilakukan dengan metode statistik uji-F, uji-t dan adjusted $\mathrm{R}$ Square dalam aplikasi program SPSS analisis regresi linier. Berdasarkan hasil pengujian, penelitian ini mampu memberikan secara simultan bahwa good governance berpengaruh signifikan positif terhadap kinerja keuangan pemerintah daerah kabupaten pangkajene dan kepulauan. Dengan ditemukan $\mathrm{H}_{\mathrm{a}}$ diterima. Apabila diuji secara parsial maka, didapatkan bahwa good governance berpengaruh signifikan positif terhadap kinerja keuangan. Hal ini terjadi mungkin karena hak pegawai diberikan secara proporsional. Angka R Square atau adjusted R dari hasil penelitian ini adalah sebesar

0,450 yang berarti bahwa variabel dependen (kinerjakeuangan) dapat dijelaskan oleh variabel independent (pemberlakuan good governance) yang dimana apabila nilai adjust $\mathrm{R}^{2}$ dimulai dalam jumlah presentase adalah sebesar 4,5 $0 \%$.

\section{DAFTAR PUSTAKA}

Abdul H., M. Yunus, dan Sulaiman. 2015. Pengaruh penerapan good governance terhadap kinerja pegawai dan dampaknya terhadap kinerja dinas pertanian dan peternakan Kabupaten Bireuen. Jurnal 4(4).

Amelia Adinda Nancy Supit,dkk. 2014. ISSN 2303-1174 Analisis Kinerja Non Keuangan PT. Otsuka Indonesia Cabang Manado. Jurnal. Vol.2 No.2 Juni 2014. Fakultas Ekonomi dan Bisnis, Jurusan Akuntansi Universitas Sam Ratulangi Manado

Dwi Susanto, dkk. 2015. Pengaruh Good Governance Terhadap Kualitas Pemberian Layanan Publik. Jurnal paradigma 12(2)

Dwi Susanto, dkk. 2015. Pengaruh Good Governance Terhadap Kualitas 
Pemberian Layanan Publik. ISSN : 1693-0827 Jurnal Paradigma 12(2): 75

F Daus AR . 2016. Dialog Publik, Dinas Kesehatan Pangkep, Pansus Kesehatan DPRD, Pelayanan Kesehatan, Puskesmas, RSUD Pangkep

F. Ekhomawaty. 2012. BAB III Metode Penelitian.

eprints.walisongo.ac.id/742/4/082411 097_Bab3.pdf. internet. dikutip pada 13 agustus 2017 pukul 23.22 Wita

Garnita, N.. 2008. Pengaruh Akuntabilitas Terhadap Kinerja Instansi Pemerintah. Skripsi.

Handi, Y. L. dan B. Jatmiko. 2016. Key Success Factor Good Government Governance serta Pengaruhnya Terhadap Kinerja Pemerintah (Survey pada Pemerintah Kabupaten Gunungkidul) jurnal 5(1)

Indonesian Institute For Civil Society (INCIS) (2005) Defisit pelayanan publik: survei persepsi masyarakat terhadap pelayanan publik di DKI Jakarta

Intihanah dan Nur Afifa Muthia S. Pengaruh Partisipasi Anggaran dan Good Governance terhadap kinerja Pemerintah daerah (studi pada dinas kesehatan kota Kendari). Jurnal akuntansi dan keuangan fakultas ekonomi dan bisnis UHO

Ira, A., D., Nur Azlina. Pengaruh good governance, pengendalian intern, dan budaya organisasi terhadap kinerja pemerintah daerah (studi pada satuan kerja pemerintah kabupaten pelalawan) jurnal.

Khafid. 2008. Penerpan Prinsip-Prinsip Good Governance dalam Kaitannya Kepuasan Masyarakat Terhadap Pelayanan Publik

Kountur, R. 2005. Statistik Praktis. Jakarta: PPM

Kusmayadi, D. 2009. Pengaruh Pengawasan Intern dan Penatausahaan Keuangan Daerah Terhadap Good Governanment Governance. Jurnal Ichsan Gorontalo $4(2)$.

Mahsun (2006) Dalam Auditya, Lucy dkk. 2013. Pengaruh Akuntabilitas dan Transparansi Pengelolaan Keuangan Daerah Terhadap Kinerja Pemerintah Daerah. Jurnal Fairness 3(1).
Muh.

Subhan.

2016.

Http://Www.Makassarterki.com/Berit a/3403/-Kinerja-Skpd-Pangkep-JauhDari-Target.

Nining Ade Ningsih, Indar, dan Amran Razak. Analisis Hubungan Prinsipprinsip Good Governance dengan Kinerja Pegawai di Dinas Kesehatan Kabupaten Luwu Timur. Jurnal

Nur, A. dan I. Amelia .2014. Pengaruh Good Governance dan pengendalian intern terhadap kinerja pemerintah kabupaten pelalawan. Jurnal akuntansi universitas jember 12(2)

Permenpan Nomor 53 Tahun 2014 Tentang Petunjuk Teknis Perjanjian Kinerja, Pelaporan Kinerja Dan Tata Cara Reviu Atas Laporan Kinerja Instansi Pemerintah.

Perpres Nomor 29 Tahun 2014 Tentang Sistem Akuntabilitas Kinerja Instansi Pemerintah.

Pertiwi, S. H. D. 2017. Analisis Implementasi Prinsip-Prinsip Good Governance Pada Pemerintahan Desa Nepo Kecamatan Tanasitolo Kabupaten Wajo. Skripsi.

Makassar: Departemen Akuntansi Fakultas Ekonomi dan Bisnis Universitas Hasanuddin Makassar

Siregar, M. A. 2008. Penerapan Tata Kepemerintahan yang Baik dalam Penyelenggaraan Pengadaan Barang dan Jasa Pemerintahan Provinsi Bengkulu. Tesis

Siti, A., Karmizi, dan E. Savitri. 2014. Pengaruh Good Governance, gaya kepemimpinan, komitmen organisasi dan budaya terhadap kinerja pemerintah daerah (studi pada pemerintah daerah kabupaten kampar). JOM FEKON 1(2)

Soemantri Yusuf, Dedy (2009) Pengaruh Good Governance Terhadap Kinerja Pemerintah Daerah Kota Bandung

Sugiyono. 2009. Metode Penelitian Kualitatif, Kuantitatif dan R\&D. Bandung: Alfabeta

Syafitri, N. 2016. Analisis Perbedaan Kinerja Keuangan Sebelum dan Setelah Akuisisi dan Merger pada PT. Xl Axiata, Tbk. Jakarta.Skripsi

Tri, E. S. dan Suyatno. Bukti Empiris Penerapan Prinsip-prinsip Good Governance pada Kinerja Koperasi di Sukabumi. Jurnal riset akuntansi dan perpajakan $1(2)$ 
Trisnaningsih, S.2007. Indenpendensi

Auditor dan Komitmen Organisasi

Sebagai Mediasi Pengaruh

Pemahaman Good Corporate

Governance, Gaya Kepemimpinan dan Budaya Organisasi Terhadap Kinerja

Auditor. Jawa Timur: Simposium

Nasional Akuntansi X

Wala, S. N. 2015. Pengaruh Good Governance dan Akuntabilitas TerhadapKinerjaInstansiPemerintah( SurveipadaDinasSKPDKabupaten Ciamis)jurnal 